\title{
Multiculturalism Represented in Adit and Sopo Jarwo Animated Series
}

\author{
Emma Rosana Febriyanti \\ English Department \\ Faculty of Teaching and Education \\ Universitas Lambung Mangkurat \\ Banjarmasin, Indonesia
}

\begin{abstract}
Multiculturalism is an umbrella term that makes people from various cultures in a community share equal respect and acceptable for each other. Multiculturalism should be introduced earlier for children since they are living in globalization era where one cultural identity may disappear easily and this can be learned in many ways. However, if it is related to children, it should be taught in fun ways in order to have more meaningful significance for them. One way that can be used by parents or any educators to encourage multicultural education is by using film animations that are closely related to children's environment, such as Adit and Sopo Jarwo animation series produced by Indonesian's talented people. This animated series represents culture of Indonesia and brings multicultural messages shown by the characters through the language spoken, the setting, and the narration. This article explains how Adit and Sopo Jarwo animation series give examples of multiculturalism as people from different ethnic backgrounds are at one place and live harmoniously together as one community. It is expected that children can appreciate differences or similarities that are shared by the people around them and make them becoming persons who are able to function effectively in the multicultural society of Indonesia.
\end{abstract}

Keywords: culture, multiculturalism, children, animated series, Adit and Sopo Jarwo

\section{INTRODUCTION}

Indonesia as the fourth largest population in the world (after China, India and the USA) is a home for people who come from different ethnics, cultures, tribes, and characteristics whose speak variety of languages and dialects and also share various traditions. They live on more than 3000 islands, including five large islands, namely Sumatra, Java, Kalimantan, Sulawesi, and Irian. It is also a place of six religions: Islam, Protestant, Catholics, Hindu, Buddha and Confucians. One can find Banjarese, Minang, Madurese, Bataks, or Javanese who are living harmoniously at the same village and they are probably Moslems, Protestants or even Buddha. Marriages could also take place among these people. This phenomenon is happening in every region in Indonesia; therefore, Indonesia is a good example of a multicultural community living together peacefully. This way of life is reflected in Indonesia motto "Bhinneka Tunggal Ika" which means "Unity in Diversity" and Pancasila as the National Principle.

This national motto and the principle embrace all differences among all people in Indonesia; no matter where they are from, what community they are in, or what religious they have, they are Indonesians. Every differences that the people have, contributes towards enriching the diverse culture of the nation. Though there are some majorities of ethnic groups, none should be considered more dominated than others. Therefore, being multicultural has been part of Indonesian's daily life. However, being part of multicultural society does not mean that we reject or eliminate our own identity or culture then change them to what others have or like. It does not happen like that. Being multicultural is that we develop an understanding that every culture is unique and we must accept others for what they are.

The diverse cultures of Indonesia cultivate the national culture as the identity of Indonesia. For instance, the government sets Bahasa Indonesia (Indonesian language) as the unifying language (Bahasa Persatuan) which can be used all over Indonesia to adjust local languages. Javanese people cannot use their local language in order to be understood by native Banjarese, and vice versa. Therefore, Bahasa Indonesia as the national language is needed by them in communication. Nevertheless, because of multiculturalism, one can understand and even speak languages from other ethnic groups especially if they stay side by side for some times. Javanese people can speak Banjarese well if they interact with Banjarese people often, and so do Banjarese people can communicate in Javanese.

Shweder (1993) in [1] provided four standpoints of receiving cultural differences, namely 1) Downward evolutionist, means that we should look down on this foreign culture/cultural practice, 2) Upward evolutionist, means that we should look up to this culture/cultural practice, 3) Universalist, we see this culture/cultural practice as superficially different from us but as being fundamentally the same, and 4) Relativist, we know that this cultural practice is different, but we should feel fully comfortable about doing it in the context of other culture. This way of thinking should be shared to our children and we help them to apply the framework to their own lives [1].

Nonetheless, there is no perfect society. In differences, there might been some misunderstandings, 
misinterpretations, or confusions about other cultures that can lead to conflicts. If these conflicts are kept without any settlement, it is feared there will be "war" among Indonesians themselves. This is what we are afraid of - that it is going to happen again in the future. In order to have peaceful Indonesia, there are many things that we can do to encourage cultural understanding among Indonesian people especially for young generations. They should realize that they are part of Indonesia multicultural society and that "feeling" should stay forever in their hearts and minds. Culture is not merely a customary belief that is passed down from one generation to the next-it is shared and also learned [2]. That is why multicultural education important especially for children so that they can appreciate, maintain, and preserve the diversity of Indonesia despite any critics arise against multiculturalism [3].

\section{DISCUSSION}

\section{A. Multicultural Education}

Multicultural is derived from the word "multi" means "many" and "culture" is "a way of life; the context within we exist, think, feel and relate to others. It is the "glue" that binds a group of people together" [4]. Culture is also referenced to "all the factors that pattern an individual's ways of thinking, believing, feeling and acting as a member of society" [5]. Therefore, multicultural is about having understanding in spite of many culture differences one to another. Additionally, multiculturalism is a term that views people from different culture to respect each other and accept its diversity as something that unites them, whether they come from majority or minority groups. Lewis (2008) in [6] mentions that multiculturalism could exist to a nation that admits its cultural diversity and takes benefits from its cultures such as Indonesia. In Indonesia, theoretically, none is asked to change his/her cultural identity into others, but it is mostly about how the member of one group can participate equally within his/her group and to other groups. In other words, being part of multicultural society means that one cannot possess the feeling as the most superior or the right one only while others are considered or judged as the weakest or worst (known as ethnocentrism)[6]. The essence of multicultural society as mentioned in [7] as "an ideal society" where many groups live harmoniously, without having fear to act their own religion, having their own linguistic or social customs, and what is more, they are all equal and have the same rights as citizens of Indonesia. All cultures and the people within one culture deserve to be recognized and appreciated. Therefore, the belief that one culture is much better than others should be lessen or diminish by having multicultural education.

Multicultural education can be defined as an education that promotes understanding and respect to human differences related to their cultures in order to create harmony and equity among its people. Mahfud (2006:179) in [8] states that, "Multicultural education sees human being widely, it is not only limited on racial side but multicultural education also about unfairness, poverty, oppression, backwardness of minority in various sides; social, culture, economy, education and etc." He also adds that multicultural education is about educating people to respect dissimilarities and teaching tolerance among society to create a peace in social society relationship.

Everyone should realize that what we think is appropriate in our culture, may be seen by others as rudeness or harassment. When children grow up in a society, they internalize the rules of their own culture and naturally become their way of thinking. However, when they step into another culture and experience different things, though at first they may find it is hard and a little bit shocking, they should understand that they live in a community with people having many different background [1]. As a country rich in culture, Indonesia is sensitive to conflicts and problems among individuals or groups from different groups. To prevent them, it is important to grow "The feeling as One" to every heart of its people and it can be achieved from multicultural education.

Gollnick and Chinn (1990) in [7] recommend five goals for multicultural education. These goals also emphasize issues beyond the boundaries of ethnic or racial issues, namely: 1) the promotion of strength and value of cultural diversity, 2) an emphasis on human rights and respect for those who are different from oneself, 3) the acceptance of alternative life choices for people, 4) the promotion of social justice and equality for all people, and 5) an emphasis on equal distribution of power and income among groups. From these goals, it can be concluded that by having multicultural education, we should acknowledge, affirm and respect the diversity among the society, accept one way of life, and consider that each person is equal in every way.

Multicultural education should be introduced earlier at young age especially since they will become the substitutes for older generations. These children will inherit Indonesia one day. They will turn into important people that lead Indonesia to its destiny in the future. Without having good knowledge about Indonesia with its plurality and diverse cultures, they will turn Indonesia into chaos. It should be argued that when the children live in this globalization era, it also means that they live in an unlimited, boundless world. When they cannot take advantage of this era, they will be dragged down into "darkness" as well as losing their identity as Indonesian people who have respective and valuable identity, ideology, cultures, religions and many more. As the children getting old later, they will observe that their own children do not possess the culture that they have as everything changes: the old disappears and newer ones emerge.

Culture has a huge influence on our daily life and as for our children. Ref [1] state that we should help our children to become more aware of their target-culture norms behaviors, to recognize and understand more about other cultural beliefs and norms, to look a little beyond cultural stereotypes and develop more empathy towards other cultures, and to develop a much more profound awareness of their home culture. By doing these, we help our children to become a better person in the future who valued their rich and varied world. 
Promoting an understanding about multiculturalism for children not only can be done at school, but also at home through television as a medium. Children like to watch TV and can sit by hours (though they sometimes do something else), if it displays cartoons or anime (the first term is originated from America, while the latter is from Japan as cited in [2]. Children love animations (the general term for cartoon and anime) for some reasons, such as they are fun to see, colorful, moving, and attractive, have interesting story, voice and music, and some others. However, parents should monitor and limit what kind of animation program that is suitable and appropriate to watch by their children. Though the programs are in the form of cartoons or animations, some of them teach violence, bullying, cruelty, pornography, and other bad things that should not be seen or imitated by the children. Therefore, parents should accompany their children when they are watching TV and give them explanation or understanding about the programs especially when they are still too young to comprehend the meaning of such stories. Ref [9] emphasize that media exposure influences cognitive development and academic achievement: when the children are exposed to pure entertainment and violent content in particular, is associated with poorer cognitive development and lower academic achievement. Thus, by selecting the programs, parents can lessen the negative effects of watching $\mathrm{TV}$, and at the same time, promoting multicultural understanding.

There are some animation programs or series for children that are suggested by the writer to watch, such as Adit and Sopo Jarwo and Upin Ipin. These two animations series are worthy to watch since they demonstrate and give examples of a peaceful life of one community from the people of various religions, ethnics, languages, and customs that reflect multiculturalism. At the same time, both animations offer entertainment as well as education. However, this article limits its discussion to Adit and Sopo Jarwo only since the writer tries to explore Indonesia multiculturalism represented in this animation series.

\section{B. Children's Animation Series}

Animation was taken from the Latin word "anima" which means soul, life, alive. It means to give life or the nature of living things on inanimate objects [10]. Dictionary of Media and Communication defines animation as "a moviemaking technique of showing slightly different drawings in rapid succession, creating the illusion of continuous motion". Meanwhile, Adinda and Adjie (2011) in [10] state animation is a continuous series of fast motion pictures that have relationship with each other. Literary, animation is a film that is the result of processing a hand image so that it becomes a moving image, in other words, we give a "life" to something that is not alive and as a result, the object looks "alive" because it is being moved.

Television as one of media in transferring information for communities and individuals, plays important role in delivering good messages and cultural values through the content embedded in the story of children's animated series. The animations are often regarded as a medium to describe the culture and values of one nation as well as a way of establishing its identity, and also help develop various skills and abilities among children (Frey \& Fisher, 2004) in [11]. Through this program, children learn about right and wrong, sadness and happiness, good and bad, imaginary and reality, love and hatred, life and death, friends and foes, as well as some other important aspects in life which reflected well in the story. Most of children's animated series aired by Indonesian TV channels are from abroad and indeed display the culture where the animation is produced. As [2] state, "to find out the cultural origins in animations or series, one has to observe the source location of where or for whom an animation is produced and cross-reference the characteristics of the animation with its local culture". For example, Shiva, Super Bheem, and Little Krishna are from India; Upin Ipin, Pada Zaman Dahulu, and Boboiboy are from Malaysia; Pokemon, Naruto, and Doraemon are from Japan; Sofia the First, Spoongebob Squarepants, and Sherif Callie Wild West are from America; Pororo the Little Penguin and Larva are from South Korea; Timmy Time and Shaun the Sheep are from UK. While from Indonesia, there are Syamil and Dodo, Adit and Sopo Jarwo, Keluarga Somat, and Kiko.

Most of those animations are considered successful in bringing the makers' cultures. For instance, in India, Shiva, Bheem, and Krishna are known as the names of Indian mythological characters. They are famous with their own strength and ability as God and super humans against evil power and they can overcome almost any obstacle they are forced into. Krishna is the god of compassion, tenderness, and love in Hinduism and is one of the most popular and widely revered among Indian divinities. As in Little Krishna, they portray him as a young boy eating butter, playing a flute, playing around with his brother Balaram and some friends, and defeating all daemons who trying to kill him under the command of King Kansa with his power which he maintains his composure and never uses it beyond that which is necessary [12]. Meanwhile, Shiva and Bheem in the series are described as young boys who have super power. They combat any villains who try to damage or harm the people in their area. They also have friends who always support them and never have the feeling of jealousy though they know that Shiva and Bheem have anything that they want to be. Those characters effectively depict Indian cultures and identity, and moreover, children are very fond of them.

The animation being studied in this article is Adit and Sopo Jarwo as it is produced and made in Indonesia. Meanwhile, the children mention here are the children at the age of $2-11$ years old which according to Piaget (1972) as cited in [13], are on the preoperational stage $(2-7$ years) and concrete operational stage ( $7-11$ years). In these stages, children are centered on the here and now, they possess natural curiosity, have short attention span when it comes to something they do not like, and they need to utilize all five of their senses to be stimulated in order to help them internalize concepts. In animations, they can have all those worked. The colorful images, the interesting audio (including narrations, music, and sound effects), and the attractive storylines or themes are able 
to encourage their curiosity and apply all of their senses in a fun way. They utilize their psychomotor, sensory, auditory, as well as their cognitive skills. In addition, Wilson (2010) in [14] states that animation not only can influence children's cognitive and academic skills, but can also determines children's social interactions, identity and development. Any stories, told or read, can influence a child emotionally and shape his or her thinking skill as well as may encourage someone to make right or bad decision (Brand, 2001) in [11]. Therefore, the choice of the story and the moral aspect contained in it are important and should be considered for any parents. Frequent exposure to such stories with active thinking will help children formulate the concept of right and wrong and shape up positive attitudes. With the help of their surrounding people, children are expected to take the essence or moral values to be adopted and practiced in their daily lives. In relation to this article, animations can be a very helpful aid in helping children learn about multicultural values.

\section{Multiculturalism In Adit And Sopo Jarwo}

The children's animated series that will be discussed is Adit and Sopo Jarwo. This animation wikipedia was released for the first time on January 27, 2014 on MNCTV. The program had aired on Global TV and Trans TV. Lately, since September 10, 2017 it broadcasted again on MNCTV [15]. The story is about Adit and Sopo Jarwo and friends who live in Karet Berkah village, the suburbs of Jakarta. Aiming children as a target of audience with parental guidance, this animated series is full of multicultural education seen in each episode which can be seen from the characters, the language spoken, the setting, and also the storyline. Despite any critics about this animation (Basid, 2016) for some scenes that promote bullying, violence or domination of one ethnic group, yet this animation deserves two thumbs up for its bravery to display some cultural diversities of Indonesia [10]. There are 135 episodes totaled for the series since it is aired for the first time [15]. The following is the discussion of the characters and multiculturalism represented in some episodes of Adit, and Sopo Jarwo animated series.

\section{The Characters}

There are some characters perform in Adit and Sopo Jarwo the series who represent the diverse cultural or ethnic groups in Indonesia. As the title of the animation, Adit is one of the main characters who was born in Jakarta, 2002. He lives with his mother and father, and has little sister named Adel who was born in 2013. He is surrounded by many friends such as Dennis, Mitha, Ucup, Kipli, and Devi. Adit is described as a smart boy who becomes a motivator as well as inspiring his friends, especially Dennis. He respects his parents very much and helps them always. He likes cycling, playing football, doing some adventures, and still sitting in the elementary school (though there is no scene about him going to school).

The second main character is Sopo, an unemployment and a slow thinker who has an overweight body. He was born in Brebes (one regency in Central Java) in 1983. He is very childish and sincere, that is why he often used by Bang Jarwo. He follows Bang Jarwo everywhere and always does what Bang Jarwo told him to do since he thinks that Bang Jarwo is his boss, for example washing the dishes for Kang Ujang.

The third main character is Bang Jarwo. He is also unemployment but is willing to do anything for money. He is described as a talented person who is able to do anything and sometimes does "a short-cut" to get the money although everything ends tragically for him. He can become a cook, a babysitter, a seller, a singer, a creator, and so on. He was born in Lamongan (one regency in East Java) in 1977. Previously, Sopo and Jarwo worked for Kang Ujang by washing the dishes to pay their debts, but now, they work for Baba Chang as helpers in his store. Additionally, he often thinks that Adit will do some damage or trouble, that is why in many scenes he, Adit and Sopo are seen chasing for each other.

The next characters are Adit's close friends, namely Dennis, Mita and Devi. Dennis is a fat boy who always feels terrified in anything, especially when he meets Bang Jarwo. He can easily panics once he is asked to do something. Adit is the one who always gives him support by saying, "Tutup mata kamu dan bayangkan..." (Close your eyes and imagine that...). Mita and Devi are also Adit's close friends. Mita is a kind of boyish, while Devi is like "Barbie girl". They like to have Adit among them. Additionally, there is Ucup, younger than Adit, who has a very long name, Muhammad Yusuf Mustaqim Firdaus Abdullah Karim Al-Ghazali Bin Abdul Qodir, and always mentions, "Kata Pak Haji..." (Pak Haji says that....) at the beginning of his sentence or "Kalau tidak percaya, tanya aja Pak Haji" (If you don't believe me, ask Pak Haji) at the end of his sentence.

Haji Udin is displayed as a wise character who gives solutions to any problems usually posed by Jarwo, and this makes Jarwo respects him very much. His words are full of good advice and usually appears almost at the end of the episodes to mediate anyone who is in dispute. He was born in 1963 and from Betawi. Next character is Kang Ujang who acts as a bakso seller and he often uses rhyme in every words he is saying. Kang Ujang is Sundanese.

Baba Chang is a new character who first appeared on the second season (March 21, 2015), and is from China ethnic. He has a shop selling daily needs and it is the place where Sopo and Jarwo work now. He has a beautiful daughter Li Mei, a college student, whom Jarwo is having a crush with. Jarwo is trying everything to get closer with her. However, Mei is paying no attention to every effort made by Jarwo.

Some of the minor characters shown in the series are Pak Daisuki who always asks Sopo Jarwo to do household chores; Pak Anas who speaks in a loud voice since he is from North Sumatra; and Mamat who is also a villager of Karet Berkah.

\section{E. Multiculturalism represented in the series}

Ref [2] states that the culture of one nation and its identity can be characterized in many different ways, and as in animation, it can be seen from physical appearance of the characters, the storylines, and even the language they speak. 
As the Bhinneka Tunggal Ika motto stated, "Berbeda-beda tetapi tetap satu", the characters in Adit, and Sopo Jarwo are from many different ethnics in Indonesia, such as Betawi, Java, Sunda, Batak and even Tionghoa, yet they are Indonesians. Moreover, multiculturalism in Adit, and Sopo Jarwo is depicted in many ways, such as the origin of the characters which illustrated from the language or accent spoken by them, the setting of the story as well as the narrative.

\section{1) The ethnic groups}

The culture that someone has can be identified from the language speak, food, clothes, ceremony or festivals, and many things. Hence, to recognize one culture easily can be done by listening that person speaks a language as it is one's identity. Since the characters in Adit and Sopo Jarwo are from many different ethnics in Indonesia, Indonesian language unites them very well. However, some linguistic patterns range from pronunciation, pitch, or accent influence the way how the characters speak. Even though they speak in Bahasa Indonesia, the audience can immediately recognize from which ethnic that this character belongs to heard from the typical accent that one ethnic group performed; it indicates that each ethnic group has its own speech style. Additionally, some of the characters are not perfectly use Bahasa Indonesia since they combine it with local language or mother tongue of their own ethnic, yet this is not a problem for another characters from different ethnics. This situation reveals multicultural understanding of one ethnic group to another and exposes a view that every person is unique with his/her own way. The following paragraphs talk about which ethnic the characters are from and some examples of the language that mark one character ethnic identity.

The main character in the series is named Adit as its name is common for Indonesians; it does not belong to any ethnic in Indonesia. Adit and his family are potrayed as a modern family of Indonesia in which the parents have two children, Adit and Adel (as the family planning program from the government: two children is enough). Bunda (Adit's mother) is a housewife who dedicated her life for the family even though she is an educated person. Ayah (Adit's father) is the only one who works as it gives picture of Indonesian family in common. Therefore, Adit's family is the general description of Indonesian family. They use Bahasa Indonesia in every situation of their daily activities.

Meanwhile, Sopo and Jarwo are from Java since Javanese people usually use vowel "o" for their name and to mention other things. Moreover, we can surely know that Sopo and Jarwo are from Java because they use "medhok" Bahasa Indonesia when they are talking. This "medhok" is very unique since it is only shared by people who come from Java and this accent is part of the Javanese culture. Besides using Bahasa Indonesia, Sopo and Jarwo also use Javanese language when they are communicating to each other. Another thing that the series shown is an acceptance with another culture such as the use of Bang (addressing term for a man from
Betawi) to mention Jarwo even though Jarwo is from Java, however, he lives in Betawi land (Jakarta).

Next is Pak Haji Udin from Betawi ethnic. Betawi people are often described as the native Jakartans, the real descendants of the people living in and around Batavia around the $17^{\text {th }}$ century [16]. Pak Haji usually uses "ente" or "elu" to address someone else, "ane" or "aye" to address himself and the use of vowel "e" at the end of the words such as "kite" (us), "pake," (use) or "punye" (own) which indicate Betawi language.

Another ethnic group shown in the series is Sunda (one major ethnic in West Java) which performs by Kang Ujang (Kang or Akang is the term of addressing for a man used by Sundanese). He is a bakso seller whom Sopo and Jarwo work for beforehand. The intonation of the sentences uttered by Kang Ujang is very unique as well as "medhok" for Javanese, and also the use of pantun (rhyme) in his utterances (usually 2 lines), such as "Bukannya saya tidak mau... tapi saya harus waspada selalu, biar semua tidak mudah berlalu!" (It doesn't mean that I don't want to...but I have to stay alert, so everything doesn't go easily) and "Ati-ati atuh kalau jalan, boleh pelan-pelan, tapi pandangan harus tetap kedepan!” (Be careful, it is ok to slow down, but you have to look front).

There is also Batak ethnic from Medan, North Sumatra which is portrayed by Pak Anas. We can easily find out that Pak Anas is from Batak since he uses high pitch in his speech which makes Sopo and Jarwo are afraid of him. People from other ethnic groups might think that Batak people are badtempered, but actually they are not. This is indeed the unique language characteristic that only Batak ethnic has.

The last ethnic group shown by the series is China ethnic or called Tionghoa portrayed by Baba Chang and his daughter Li Mei. Baba is a term for addressing a man in Tionghoa ethnic. Not only from the names, Tionghoa ethnic in this animation is also described by the physical appearance of the characters such as slanted eyes, oriental face and white skin. Whereas for the language, Baba Chang uses consonant "l" to replace "r" such as "olang" for "orang" (people), "walung" for "warung" (shop) and "oe" (I), "lu" (you) to show how the typical Tionghoa people usually talk. Additionally, Tionghoa people are often identified as traders, thus, Baba Chang has a shop to say that he is also a trader. Meanwhile, from the language, $\mathrm{Li}$ Mei is presented to be as a modern Tionghoa who does not have China accent as part as her interaction with another major ethnic group or Indonesian people in general.

Moreover, if we pay attention more closely, there is one more ethnic group in Indonesia being introduced. In this series, Dennis always wears a T-shirt with Balinese Barong image (a masked figure as the symbol of health and good fortune). The T-shirt with this image can easily be found in souvenirs shops in Bali since Barong is part of Balinese culture. Thus, the animators tried to introduce Bali culture to Indonesian children since there is no character made for this. However, Bali is not only famous for its beautiful island, but also its richness in culture.

This character establishment in Adit and Sopo Jarwo animated series exposes Indonesian multicultural mix of 
ethnic that are able to communicate and live together peacefully in one place. None of the ethnic group in Adit and Sopo Jarwo has to assimilate with another dominant group, in this case, Betawi or Javanese ethnic group as the dominant culture. According to [6], assimilation is the process by which groups adopt and change the dominant culture; however, multiculturalism which promotes by Adit and Sopo Jarwo animated series permits other ethnic groups to maintain their cultural identities without having to change them into the dominant one.

\section{2) The setting}

According to Dictionary of Media and Communication (2009:267), setting is the place and conditions in which a narrative, play, or poem takes place. Additionally, Abdul Ghani (2015:246) states that the setting or the visual background of a scene is vital in supporting the mood or scenario that will integrate with the characters involved. He also adds that "the choosing of location or background scenes are one of important aspects of animation or filming, just as finding the right actors to portray a role, and just as important as the choice of music used in the film" (Sandy, 2011 in [14]).

In this animation series, Karet Berkah village becomes the location where Adit and Sopo Jarwo animated series is taken place. It is located in the suburb of Jakarta. Jakarta is the capital city of Indonesia and similar to a big city in general, it is the place where people from all out Indonesia gathered, which also means that people from different ethnic background assembled into one. They come to Jakarta for many reasons; then, some of them become Jakarta residents and some of them stay temporarily. Thus, it is not difficult to comprehend that the village is full of people from different ethnic background and then becomes the setting of Adit and Sopo Jarwo animated series.

The village is visualized as a safe and peaceful place in which the villagers from variety ethnic background are still doing communication face to face. They meet on the street and greet each other in a friendly manner. Next, unlike houses in the city, some of the villagers' houses are still made of wood and there are no high fence surrounding the house. Although there is no traditional house belongs to one ethnic or the character appears in the story, Adit and Sopo Jarwo has successfully portrayed a friendly neighborhood where different ethnic groups represented by the characters can live in harmony.

Next, in Karet Berkah village, there is an empty area which becomes the setting of most scenes. This place is used by Adit and friends to study as well as their playing ground to play football, badminton, or doing other traditional games. Adit and his friends are never visualized using gadgets or having any technology related to modern world besides TV. By doing this, it is suggested that Indonesian children should not depend on gadgets and make use of their time by playing outside or doing some physical activities.

The setting in this animated series can move from Kang Ujang's bakso cart to Baba Chang's store, or to Adit's house and the streets, and some other places. All places in Karet
Berkah village are described well to support the characters' role and to display the peace neighborhood.

Adit and Sopo Jarwo is an animated series that can be watched by anyone at any age though it is made for children. This animated series can be used as a mean or medium to deliver messages about multiculturalism for children. By seeing the characters and the story, children can learn that they are not alone - they share the world with the people around who might have differences with them.

\section{3) The narrative}

The reflections of Indonesian culture and acceptance of another culture are emphasized in some episodes of Adit and Sopo Jarwo. These episodes are chosen purposively based on consideration that there is a cultural property shown in the episode.

The first episode is Latihan Wushu yang Seru. In this episode, wushu is introduced by Baba Chang as this martial art originated from China. Here, Pak Haji appraised Baba Chang who performs the wushu movement smoothly, and when Adit and Dennis saw this performance, they wanted to learn it also.

The next episode is Festival Perahu Kertas Berlayar Tanpa Batas. It is told that Kampung Berkah village is having a paper boat festival; Adit and friends also join the competition. When they are making the boat, Sopo and Bang Jarwo come to help by bringing cardboard. Dennis got the idea that the boat should be named "Pinisi". Pinisi is a sailing boat originated from Bugis, Makasar (South Sulawesi) which generally has two main pillars (as the symbol of Syahadat) and seven supporting poles (as the sum of surah Al-Fatihah). Pak Haji also said in his opening speech that Indonesia is a maritime country and our ancestors are sailors, and as young generation who live in Indonesia, Adit and friends and other villagers should preserve Indonesian culture. It is seen in this episode that Adit and his friends imagining that they are sailing from Sabang to Merauke by using Pinisi boat.

Next is Senandung Angklung Warga pun Kagum. Angklung is a traditional music instrument made of a varying number of bamboo tubes attached to a bamboo frame and is played by holding the frame on one hand and shaking the instrument by using the other hand which causes a repeating note to sound. It has become the cultural identity of Sundanese communities in West Java and Banten. In the episode, Adit and friends and some of the villagers are practicing playing angklung for art performance held in the village.

The next is Sebuah Jasa Yang Tak Disangka. Here, the ethnic being shown is Batak performed by Pak Anas. Pak Anas feels homesick, thus, he sings "Butet" which means "daughter". This song is about a father who misses her daughter since he is away for a war. If someone sings this song, everyone who heard it will immediately say that this song is from Batak.

The last one is Jago Silat Lawan Penjahat in which Pak Haji performs some Pencak Silat moves. Pencak Silat is a traditional martial art from Indonesia and is widely known by our neighborhood countries. Therefore, there are two martial 
arts introduced in Adit and Sopo Jarwo: wushu and pencak silat which perform by two different people (ethnics).

Beside those episodes mentioned above, there are things that children should know about Indonesia and its rich culture. Adit and Sopo Jarwo tries to introduce tahu Sumedang in Tahu Sumedang Bikin Jarwo Meradang episode which originated from Sumedang (West Java) as one of famous Indonesia culinary food and we can find it anywhere in Indonesia. Another one is in Bikin Tumpeng Enaknya BarengBareng episode. Tumpeng is a way of serving rice with some dishes in its side in the cone form which originated from Betawi or Java and usually made for important events. However, tumpeng is popular in Indonesia and anyone from any ethnic group can enjoy and make this.

Adit and Sopo Jarwo as an edutainment program also attempts to make known some Indonesian fruit such as apel Malang in Apel Malang Buat Adel Senang which from Malang (East Java) and this place is famous for its sweet apples. This series also inspires children learn to create their own playing toys as in Jeruk Bali Jadi Kreasi episode. By using jeruk Bali, children can make their own toys such as cars, boats, and even flowers.

Lastly, this animated series proposes Islamic tradition in Sunatan Masal Jangan Asal episode. Circumcision is a process that must be done by an Islamic young boy under 12 years old or any man who converts to Islam. Nevertheless, circumcision not only be done by a man but also a girl when she is still a baby.

Culture is part of life and it affects people in many ways. Then, culture can be introduced to children by using animation with the story that is related to their environment to provide understanding what is around them. By helping our children understand about who they are in the context of ethnic group, religion, or culture as part of the society, we will help them realize that they are unique among many other wonderfully unique people on this earth and how differences make our world a better place.

\section{CONCLUSION}

Children tend to mentally process what they have watched and this is one of the reasons why parents should accompany their children when they are watching TV in order to give explanation and understanding. Since children love to watch animation and with parental guidance, Adit and Sopo Jarwo animated series can be introduced to them earlier. This animation series has been quite successfully promotes Indonesian multicultural society and at same time, gives multicultural education for children. It has delivered positive messages through the representation of the characters, setting and the narration that highlight the importance of understanding and solidarity of their own and others culture. The effort to educate children through animation as in Adit and Sopo Jarwo animated series should serve as an example for other programs as this can be a powerful medium to teach children about the uniqueness of Indonesia.

\section{REFERENCES}

[1] G. Johnson and M. Rinvolucri, Culture in Our Classrooms. England: Delta Teacher Development Series Publishing, 2010.

[2]. M. Omar, M. Amir and M.S.A Ishak, "Understanding culture through animation: from the world to Malaysia", Malaysian Journal of Media Studies University Malaya. 13(2), 2011, PP 1-9.

[3] T. J. Lan, "Heterogeneity, politics of ethnicity, and multiculturalism. Wacana", 13(2), 2011, PP 279-292.

[4] H. D. Brown, Teaching by principles-An Interactive approach to Language Pedagogy. $3^{\text {rd }}$ Ed, New York: Pearson Education, Inc, 2007.

[5] A. Novita, "Addressing religious diversity in education in Indonesia", JIRE, 5(1), 2015, PP 109-119.

[6] D. M. Gollnick and P.C. Chinn, Foundations of Multicultural Education-Multicultural Education in a Pluralistic Society, 9th Ed. New York: Pearson Education, 2013.

[7] F. Hanurawan, and P. Watenvorth, "Multicultural perspectives in Indonesian social studies education curriculum", The Journal of Education, 4, special edition, 1997, pp 265-275.

[8] M. Miftah, "Multicultural education in the diversity of national cultures", Qijis, 4(2), 2016, pp 167-185.

[9] H.L. Kirkorian, E.A. Wartella and D.R. Anderson, "Media and young children's learning. The Future of Children", 18(1), 2008, pp 39-61.

[10]. A. Basid, "Pesan multikultural dalam serial film animasi anak Adit, Sopo, dan Jarwo. Penamas", 29(3), 2016, pp 493-504.

[11]. W. M. Wan Isa, M.A. Mat Amin, A.W. Rozaimee, W.M.R. Wan Idris, N. Rahim, and I. S Samaden, "Conceptual framework of edutainment animated series for children: a pious story", ARPN Journal of Engineering and Applied Sciences, 10(3), 2015, pp 11061113.

[12]. Little Krishna, In Wikipedia, 2017, Retrieved November 28, 2017, from https://en.wikipedia.org/wiki/little_krishna

[13]. S.A. McLeod, Jean Piaget, 2015 Retrieved from www.simplypsychology.org/piaget.html

[14]. D. B. A. Ghani, "Upin \& Ipin: promoting Malaysian culture values through animation. Historia y Comunicación Social”, 20(1), 2015, pp 241-258.

[15] Adit and Sopo Jarwo. (n.d.), In Wikipedia. Retrieved November 25, 2017, from https://en.wikipedia.org/wiki/Adit_\%26_Sopo_Jarwo, 2017

[16] Betawi people, In Wikipedia, , Retrieved November 29, 2017, from https://en.wikipedia.org/wiki/Betawi_people, 2017 